\title{
Royal Succession and the Canadian Crown as a Corporation Sole: A Critique of Canada's Succession to the Throne Act, 2013
}

\author{
Philippe Lagassé \\ James W.J. Bowden*
}

The constitutionality of Canada's Succession to the Throne Act, 2013 (Succession Act) will be tested in Quebec's Superior Court in the coming months. In a case brought by two law professors from Laval University, with the government of Quebec as an intervener, the Quebec Superior Court will consider whether the Parliament of Canada's assent to a British statute is sufficient to change the rules of royal succession for Canada. If the court deems the issue justiciable, which is by no means certain, the case will likely turn on three interrelated questions. First, does the preamble to the Constitution Act, 1867, which states that Canada is federated under the "Crown of United Kingdom of Great Britain and Ireland" imply, constitutionally, that Canada and the United Kingdom must have the same person as monarch? Second, does royal succession form part of Canadian law, or does British law determine the rules that govern who will be the Sovereign of Canada? Third, if royal succession is a matter of Canadian law, do changes to the law of succession affect the "office of the Queen," which can only be altered by the unanimous consent of the House of Commons, Senate, and provincial legislative assemblies under section 41(a) of the Constitution Act, 1982?

According to the federal Department of Justice, matters of royal succession are strictly a matter of British law that does not form part of Canadian law, and the preamble of the Con- stitution Act, 1867 ensures that Canada and the United Kingdom share the same person as monarch. ${ }^{1}$ This view has been supported by Peter Hogg, Benoit Pelletier, Robert Hawkins, and other prominent constitutional lawyers. ${ }^{2}$ An opposing view has been offered by Anne Twomey and the Canadian Royal Heritage Trust (CRHT). Twomey points out that since the Westminster Parliament can no longer legislate for Canada, the distinction between the Canadian and British Crowns implies that changes to royal succession must be accompanied by a Canadian law if they are to have any effect in Canada. ${ }^{3}$ CRHT argues that royal succession was incorporated into Canadian law during the Abdication Crisis of 1936 and that the existence of a separate Canadian Crown means that Canada cannot rely on British law to change the succession to the uniquely Canadian throne. ${ }^{4}$ In addition, CRHT suggests that the wording of s.41(a) makes it likely that royal succession does fall under the office of the Queen.

In anticipation of both the Quebec Superior Court case and a possible appeal to the Supreme Court, we examine an aspect of the debate that has received little attention thus far. Specifically, we argue the Queen of Canada's status as a corporation sole undermines the federal government's interpretation of the law and constitutionality of royal succession in Canada. Since the Queen of Canada is a corporation sole separate and dis- 
tinct from the Queen of the United Kingdom, the rules governing the succession of the Crown of Canada can only be altered through a change to Canadian law. Hence, the succession to the Canadian Crown does not change automatically when the British Parliament alters the rules governing succession to the British Crown. In turn, the Canadian Parliament cannot merely assent to a British statute to change the laws of royal succession for Canada. Further, since the Crown of Canada is a corporation sole, matters of succession by definition form part of the "office of the Queen," and thus fall under s.41(a) of the Constitution Act, 1982. The Queen of Canada's status as a corporation sole, therefore, complements the arguments put forth by Twomey and the CRHT.

This paper elaborates on the fundamental meaning of the Queen as a corporation sole and examines how the corporate status of the Crown undermines the logic of the Succession to the Throne Act, 2013. It begins with an examination of the Canadian Crown as a corporation sole and the purpose of granting the Sovereign of Canada this status. Next, the paper explores how the Canadian Crown's standing as a corporation sole strengthens the case that matters of succession are part of Canadian law and likely fall under s. 41(a) of the Constitution Act, 1982.

\section{The Canadian Crown as Corporation Sole}

According to the federal Department of Justice's volume Crown Law, the Crown of Canada is "a non-statutory corporation sole." ${ }^{5}$ Essentially, "a corporation sole creates a corporation out of an office. Once the corporation is established, there is no distinction between the [office-holder] and the office itself." 6 Although the office and office-holder retain dual capacities, "namely its corporate capacity, and its individual or natural capacity," they are inseparably fused in law. Accordingly, while it is possible to speak of Queen Elizabeth II as a natural person alone, and while most discussion of the Queen tends to invoke the monarch as a natural person, in matters of Canadian law, references to "the Queen," "Her Majesty in Right of Canada," or "the Sovereign" pertain to this legal, or corporate, personality. ${ }^{8}$

Constitutionally, having the Queen of Canada as a corporation sole means that this legal person personifies the Canadian state and acts as the guarantor of the rule of law and the underlying authority behind Canada's institutions. ${ }^{9}$ The Canadian state is legally a person and all state and governing authority is said to flow from this legal personality; the Crown remains "a supreme entity in which all functions of the State reside." ${ }^{10}$ As a legal person, the Crown can hold property and enter into contracts. ${ }^{11}$ In fact, it is for this reason that the state and the executive can legally act as a person. Similarly, as a legal person the Canadian state and government are "capable of acquiring rights and liabilities under common law or statute law, capable of suing and being sued, and bound by the decisions of courts and other properly constituted tribunals." ${ }^{2}$

Yet having the Crown as a corporation sole serves a more critical purpose: it ensures the perpetuity of the state and governing authority. ${ }^{13}$ Because the Queen of Canada is a corporation sole, all the decisions, authorities, and constraints that surround the Crown as the state and executive, such as those found in the Constitution and in statute, are preserved as successive natural persons occupy the office of Sovereign. Moreover, the Queen of Canada's status as a corporation sole ensures that all references to the Queen, the King, Her Majesty, His Majesty, and the Crown over time are synonymous and thus refer to the same legal personality. ${ }^{14}$ Consequently, there is no need to reaffirm the powers of the Crown, or the constraints on those authorities, upon a demise of the Crown and the accession of a new natural person as the next reigning Sovereign. Nor is there any need to rewrite any laws or clarify that previous decisions to bind the Crown are still binding. ${ }^{15}$ As a corporation sole, the Sovereign never dies in law; while natural persons who serve as monarch pass on, the legal personality they embodied lives on. Hence, it is the corporate character of the office of the Sovereign which ensures that the authority of the state and executive continue uninterrupted as succes- 
sive natural persons occupy the office of Sovereign. As Blackstone observed:

Corporations sole consist of one person only and his successors, in some particular station, who are incorporated by law, in order to give them some legal capacities and advantages, particularly that of perpetuity, which in their natural persons they could not have had. In this sense, the king is a sole corporation [...]

The king, for instance, is made a corporation to prevent in general the possibility of an interregnum or vacancy of the throne, and to preserve the possessions of the crown entire; for immediately upon the demise of one king, his successor is, as we have formerly seen, in full possession of the regal rights and dignity. ${ }^{16}$

Succession is thus integral to the Crown as a corporation sole because the Crown can never be vacant. The Crown cannot be disembodied from a natural person, which means that its very existence as a corporation sole and central institution of government depends upon the chain of persons who succeed to the office; in other words, the Crown depends on the line of succession. Succession is a necessary part of the office of a corporation sole.

Perpetuity and seamless succession, in fact, were the underlying motives behind the gradual establishment of the Sovereign as a corporation sole. Under early English feudalism, there was no need to distinguish between the monarch as a natural person and legal entity. The authorities and rights of the monarch were personal, as were the ties of fidelity and service that bound individuals to the monarch, and vice versa. As the English state and system of laws grew more complex, it became necessary to bring greater stability and continuity to the Crown. This was done by distinguishing between the monarch in a personal capacity, on the one hand, and in a political capacity, on the other ${ }^{17}$ Known as the doctrine of the "king's two bodies," the conceptual separation between the monarch's "body politic" and "body natural" allowed the authority of the Crown and royal dignity to be preserved and protected during successions. While the monarch's natural body could die, the body politic could not. Although the two bodies doctrine would later be used to distinguish between the property monarchs held as the Sovereign opposed to a natural person, the original, and still essential, purpose of making the Crown a corporation sole was to fuse monarchical predecessors and successors into a single, immortal legal personality. ${ }^{18}$ As Kantorowicz demonstrated, the Crown as a corporation originally developed as a means of ensuring automatic hereditary succession upon the death of one reigning Sovereign and the accession of another, which in turn created a perpetual legal personality. ${ }^{19}$ The continuity of peace, order, and good government depended upon the "rex qui nunquam moritur, a 'king that never dies."'20

In a Canadian context, the corporate character of the Crown serves another purpose as well: it allows the Crown of Canada, the legal person known as Her Majesty in Right of Canada, to be separate and distinct from the British Crown, the legal person known as Her Majesty in Right of the United Kingdom, while maintaining the same natural person the holder of both monarchical offices. Thus, when it is said that Canada and the United Kingdom share the same Queen, this is a reference to the monarch as a natural person, not their distinct Sovereigns as legal personalities. Canada and the United Kingdom share Queen Elizabeth II as monarch in a personal union, not a legal one; the Queen as a natural person holds the distinct offices of the Canadian and British Sovereigns, but the legal separation of those offices, and therefore of the Canadian and British Crowns, is not erased as a consequence. Insofar as the Canadian and British Crowns are distinct corporations sole, Canada and the United Kingdom are able to maintain that their Sovereigns are separate legal persons while having the same natural person as the holder of their respect monarchical offices. ${ }^{21}$

The significance of this point should not be understated. Because the Crown serves as the concept of the state in Canada and the Canadian state is the legal person called Her Majesty in Right of Canada, ${ }^{22}$ stating that Canada and the United Kingdom have the same Sovereign as a legal person, or that Canada and the United Kingdom are under a common Crown, implies that the two countries are not separate and dis- 
tinct sovereign states. Stated plainly, if Her Majesty in Right of Canada and Her Majesty in Right of the United Kingdom are the same legal person, then Canada and the United Kingdom are the same state. Indeed, it is for this reason that in 1981 the English Court of Appeal, in answering the question of whether Canada or the United Kingdom was bound by First Nations treaties, were careful to note that the Crowns of Canada and the United Kingdom had been multiplied after the Imperial Conference of 1926, and that "In matters of law and government the Queen of the United Kingdom is entirely independent and distinct from the Queen of Canada." ${ }^{23}$

For Canada, therefore, the Sovereign as a corporation sole not only ensures the perpetuity of the state and governing authority, but also provides the legal and constitutional logic behind the Canadian state's independence from the United Kingdom. Canada is only a de jure independent and sovereign state if the Crown of Canada is a corporation sole separate and distinct from the Crown of the United Kingdom.

\section{The Canadian Crown and Royal Succession}

Canada's Succession to the Throne Act, 2013 does not purport to alter the rules of royal succession in Canadian law. Instead, the statute assents to changes to the laws of royal succession for the United Kingdom that have been passed by the British Parliament. Although this approach differs from the one taken in Australia and New Zealand, where their parliaments are enacting legislation to alter their own laws of royal succession rather than assenting to a British law, the legitimacy of the Canadian act has been defended on four grounds. First, it has been argued that the Canadian statute accords with a convention set forth in the second recital of the preamble to the Statute of Westminster, 1931, which states that the assent of the Dominion parliaments is required in order to make "any alteration in the law touching Succession to the Throne or the Royal Style and Titles." 24 Second, the government of Canada and Peter Hogg have argued that the preamble of the Constitution Act, 1867, which says that Canada is "federally united into One Dominion under the Crown of the United Kingdom of Great Britain and Ireland," erects a "principle of symmetry" in constitutional law, such that the Queen of the United Kingdom is ex officio the same person as the Queen of Canada. ${ }^{25}$ Finally, it has been submitted that matters of royal succession belong to British law alone and are not part of the laws of Canada at all; hence, it is for the British Parliament alone to decide the succession to the throne. ${ }^{26}$

Each of these arguments is open to critique. The Australian and New Zealand decision to alter the rules of royal succession in their law, rather than assenting to a British law, casts doubt on the notion that matters of succession belong to British law alone and that the preamble to the Statute of Westminster is a sufficient mechanism to alter the succession for the former selfgoverning Dominions. If this convention is said to exist by virtue of the Statute of Westminster, it is worth asking why Australia and New Zealand do not recognize it, or rely on it, to alter the rules of successions to their respective crowns, the Crown of Australia and the Crown of New Zealand. On the contrary, New Zealand's royal succession law denies that such as a convention exists. The Government of New Zealand provided comments on its bill, explaining "Changes to the United Kingdom succession laws do not automatically apply to New Zealand, so the Royal Succession Bill is necessary." ${ }^{27}$ In April 2013, the Premiers of the six Australian states and the Prime Minister of the Commonwealth of Australia agreed that Australia would alter its laws on succession to the throne through section 51(38) of the Commonwealth of Australia Constitution Act, 1901, which allows the state parliaments to delegate their authority to the federal parliament so that it can legislate for all of Australia. ${ }^{28}$ The state of Queensland first introduced its Succession to the Crown Bill, whose preamble also rejects the Canadian interpretation: "It is necessary for the Parliament of the State to enact legislation for these purposes as no Act passed by the Parliament of the United Kingdom after the commencement of the Australia Acts extends to the State as part of the law of the State." ${ }^{29}$ 
Analyzing the Succession to the Throne Act, 2013 from the perspective of the Canadian Crown as corporation sole reinforces and extends this critique. As a corporation sole, matters of succession are inherent to the Canadian Crown by definition. This must be the case if the corporation is to achieve its primary purpose: to ensure the perpetuity of the Crown and seamless succession to the office of Sovereign. The question, then, is where the laws governing the succession for the Canadian Crown are to be found and what legislative power is responsible for formulating them. The Canadian government's position is that the Canadian Crown recognizes the rules of succession of another, separate, and distinct corporation sole, the British Crown, as determined by the British Parliament. Unfortunately, the government's position faces a significant problem: there is no legal precedent indicating that the laws of succession to the Canadian Crown are determined by the British Parliament, either by design or by default.

On the contrary, the fact that the Canadian government requested and consented that the British Parliament extend His Majesty's Declaration of Abdication Act, 1936 to Canada, using the now defunct section 4 of the Statute of Westminster, indicates that merely assenting to British law was not, and is not, sufficient to change the rules of succession for Canada. ${ }^{30}$ In March 1937, moreover, the Parliament of Canada directly imported the rules governing succession and incorporated them into the laws of Canada through the Succession to the Throne Act, 1937, which assented retroactively to His Majesty's Declaration of Abdication Act, 1936, and more importantly, incorporated it as part of the laws of Canada by including it as an appendix. ${ }^{31}$ The extension of the His Majesty's Declaration of Abdication Act, 1936 to Canada and the enactment of the Succession to the Throne Act, 1937 by the Canadian Parliament to Canada demonstrates that the Canadian Crown has its own rules of succession. Hence, the fact that the laws of succession were purposefully extended to Canada belies the argument that matters of royal succession are not part of Canadian law. ${ }^{32}$ Additionally, the fact that Canada could not merely assent to British law to alter the laws of royal succession for Canada in 1936 indicates that the
Canadian Crown does not automatically adhere to British laws of royal succession. Moreover, the mechanism allowing the British Parliament to legislate for matters of royal succession in Canada, section 4 of the Statute of Westminster, was repealed by the Canada Act, 1982 .

Notwithstanding His Majesty's Declaration of Abdication Act, 1936 and the Succession to the Throne Act, 1937, it has been argued that the rules of succession to the Canadian Crown mirror those of the British Crown by convention. The existence of this convention was put forth by the Ontario Superior Court in the case of O'Donohue v. Canada. ${ }^{33}$ As noted above, this convention is said to exist by virtue of the preamble to the Constitution Act, 1867, which speaks of Canada being federated under the Crown of the United Kingdom and Ireland. Of course, this was the case in 1867 when Canada was under the sovereignty of the British Crown and there was no independent Canadian state. The purpose of this wording was to identify the authority under which Canada was created and where the ultimate sovereign authority for and over Canada was found - with the British Crown-in-Parliament. Starting in 1926 with the Balfour Report, however, a distinctly Canadian Crown began to form. From that point forward, the reference to the Crown in the Constitution Act, 1867 evolved to mean the Crown of Canada. Furthermore, we know that the preamble to the Constitution Act, 1867 did not pertain to matters of royal succession, since this issue was specifically addressed in section 2 of the Constitution Act, 1867, an interpretive clause which was repealed by the British Parliament in 1893: "The Provisions of this Act referring to Her Majesty the Queen extend also to the Heirs and Successors of Her Majesty, Kings and Queens of the United Kingdom of Great Britain and Ireland."

To establish that the preamble Constitution Act, 1867 provides that Canada and the United Kingdom must share the same monarch today, it is therefore necessary to make two tenuous arguments.

The first is that the preamble remains literally true: that Canada is still under the sovereignty of the British Crown, and Canada and the United 
Kingdom must share the same monarch for this reason. ${ }^{34}$ Since the Crown is the state for both countries, this would mean that Canada's standing as a sovereign state independent from the United Kingdom is a political reality but not a legal or constitutional one. This would not only mean that Her Majesty in Right of Canada and Her Majesty in Right of the United Kingdom are not separate and distinct, despite what British law lords found in 1981, but would also imply that Canada did not attain de jure independence and sovereignty from the United Kingdom in 1982, which would contradict the finding of the English Court of Appeal. ${ }^{35}$

The second argument would be that section 2 of the Constitution Act, 1867 still applies, or should be understood to apply via the preamble, despite the fact that it was repealed. Regardless of why the British Parliament repealed this provision, the fact remains that it was repealed. Hence, an attempt to revive section 2 as a convention grafted onto the preamble would appear to be a highly questionable effort to get around an inconvenient historical fact. Furthermore, even if section 2 had not been repealed, we have good reason to think that it would either be interpreted to refer to Her Majesty in Right of Canada today or be considered obsolete. Section 2 of the Commonwealth of Australia Constitution Act states "The provisions of this Act referring to the Queen shall extend to Her Majesty's heirs and successors in the sovereignty of the United Kingdom." Notwithstanding that this provision remains in place, Australia does not consider that the laws of succession for the Australian Crown are set by the British Parliament or that a convention of symmetry exists between the Australian and British monarchs. Because Her Majesty in Right of Australia is separate and distinct from Her Majesty in Right of the United Kingdom, section 2 no longer applies. ${ }^{36}$ Were section 2 of the Constitution Act, 1867 still in place, the same would surely hold in Canada, unless it could be shown that the Canadian state failed to achieve the same degree of independence from the United Kingdom that Australia and New Zealand did.
In the absence of greater evidence or precedents, it is unclear how, or on what grounds, a foreign legislature sets the rules governing the corporate legal personality that is the Canadian state. The Canadian advocates of this hypothesis have failed to explain why the principle of symmetry applies only to the United Kingdom and Canada and not to the United Kingdom and Australia and not to the United Kingdom and New Zealand. They have equally failed to explain how this convention overrides the rules of succession that were incorporated into Canadian law via His Majesty's Declaration of Abdication Act, 1936 and the Succession to the Throne Act, 1937.

Assuming that the succession to the Canadian Crown is part of Canadian law and that Parliament cannot merely assent to a British statute to change the rules of succession for Canada, the next issue that must be addressed is whether succession is a matter that relates to the "office of Queen," which would fall under the constitutional amending formula outlined in s. 41 of the Constitution Act, 1982. Two arguments can be made against the idea that succession does pertain to the office of the Queen. First, the case might be made that s. 41 only addresses changes made to the Constitution Acts and the statutes included in the schedule. Since royal succession is not mentioned in either Constitution Act, matters of succession do not involve an amendment to the "Constitution of Canada." Second, it has been posited that alterations to the rules of succession affect the office-holder of the office of Sovereign, not the office itself. ${ }^{37}$

Both of these arguments are undermined by the fact that the Canadian Crown is a corporation sole. Although Canada's constitution acts do not refer to succession explicitly, references to the Queen in the constitution acts refer to the Her Majesty in Right of Canada, the legal personality and corporation that, by definition, includes the current monarch and successors. Indeed, it is precisely because the Queen is a corporation sole that references to the Queen in the Constitution Acts applied to the kings that succeeded Queen Victoria, and will apply to the kings and queens that succeed Queen Elizabeth II. Because the Queen as a sole corporation includes successors, 
matters of succession are implied in references to the Queen in Canada's Constitution Acts. The Queen as a corporation sole, moreover, belies the notion that matters of succession relate only to the current office-holder and not to the office. Corporations sole fuse offices and office-holders in law into one corporate personality, which then merely possesses dual capacities. Any statute that seeks to affect the office-holder necessarily affects the office, and vice versa. Nor would it be logical to suggest that succession affects the office-holder alone. Royal succession deals with who will legally be fused with the office.

Finally, although this argument has not yet been made, it could be argued that matters of succession do not relate to the office of the Queen because succession regulates the choice of which natural person becomes monarch, rather than the legal personality known as Her Majesty in Right of Canada. However intuitive this reasoning may be, it fails to appreciate the logic of royal succession laws. In our time, the rules of royal succession deal with qualifications to hold a public office. Their purpose is to determine which natural person meets the criteria to serve as the holder of that office. Hence, unlike matters of inheritance, royal succession laws do not deal with the relationship between natural persons; instead royal succession rules establish a relationship between an office and an office-holder. In a Canadian context, this means that the law of royal succession addresses the qualifications to succeed to the office of the Queen of Canada.

\section{Conclusion}

In evaluating the constitutionality and effect of Canada's Succession to the Throne Act, 2013,(Succession Act) it is tempting to have recourse to the dictum that "where the law and the facts collide, it is the law which must be brought into conformity with the facts." ${ }^{38}$ Although the legality and constitutionality of the Succession Act are quite problematic, the fact is that this statute represents an economical way of preserving the personal union between the Crowns of Canada and the United Kingdom - one that avoids a constitutional amendment and challenges to the law of succession under the Charter of Rights and
Freedoms. Indeed, it is probably to avoid constitutional challenges that the federal government chose to approach the Succession Act in the way that it did. Seen from this vantage point, its aim should outweigh the questionable legal and constitutional grounds upon which it rests.

As tempting as it is to use this logic to dismiss the legal and constitutional issues surrounding the Successsion Act, such an approach ignores the conceptual damage to Canada's standing as a de jure independent and sovereign state. However antiquated or abstract it may appear, it remains that the Crown is the concept of the state in Canada, and that the state is a legal person known as Her Majesty in Right of Canada by virtue of the Crown's status as a non-statutory corporation sole. Claims that the laws governing this Canadian corporation fall under the authority of the British Parliament, or that the legal personality of the Canadian state is still the same as the legal personality of the British state, undermines the independence and sovereignty that Canada began to enjoy after 1926 and could fully claim after 1982.

While the blurring of Canada's de jure independence and sovereignty may seem a trifling point compared with amending the Constitution of Canada, it should be noted that the Federal Government's interpretation of the law of royal succession could invite equally complicated troubles. The English Court of Appeal's finding that the Queen of Canada and the Queen of the United Kingdom are separate and distinct ensured that First Nations treaties were not binding on the British government. If this distinction between the Queens is confused, it is not impossible that this question could be revisited. More problematically, if the courts accept that British law alone decides matters of royal succession for Canada, or that Canada remains under the sovereignty of the British Crown owing to the preamble of the Constitution Act, 1867, then this interpretation raises the issue of how a transition to a republican constitution in the United Kingdom would affect Canada. Although it is high unlikely, should this ever occur, the very constitutional amending process that the Succession Act is meant to avoid could be triggered by the 
legal logic that underpins it. Hence, although it would surely take time and effort, it would arguably be preferable for the courts to acknowledge that royal succession is a matter of Canadian law and proceed with a constitutional amendment under s. 41(a) according to suitable timeline.

\section{Notes}

* Philippe Lagassé is an associate professor of public and international affairs at the University of Ottawa. James W.J. Bowden is an M.A. candidate at the University of Ottawa.

1 Succession to the Throne Act, 2013, SC 2013, c 6, Preamble.

2 Canada, Standing Senate Committee on Legal and Constitutional Affairs, Proceedings, 41st Parliament, 1st Sess, No 32 (20 March 2013) (Benoit Pelletier); Robert E Hawkins, “The Monarch is Dead; Long Live the Monarch': Canada's Assent to Amending the Rules of Succession" (2013) 7 Journal of Parliamentary and Political Law [Hawkins]; Peter Hogg, "Succession to the Throne" (2014) 33 NJCL [forthcoming in 2014] [Hogg Succession] ; Canada, Standing Senate Committee on Legal and Constitutional Affairs, Proceedings, 41st Parliament, 1st Sess, No 32 (20 March 2013) (Submission, Mark Walters' written submission on legal and constitutional affairs concerning bill C-53, 5 March 2013).

3 Anne Twomey, "The royal succession and de-patriating the Canadian Constitution," Constitutional Critique (4 February 2013), online: The University of Sydney <http://blogs.usyd. edu.au/cru/2013/02/the_royal_succession_and_ the_d.html>.

4 Garry Toffoli, "Is There a Canadian Law of Succession and Is There a Canadian Process of Amendment?" (9 February 2013), online: Canadian Royal Heritage Trust <http://crht.ca/wpcontent/uploads/2013/02/CRHT-BackgroundPaper-on-Canadas-Law-of-Succession.pdf $>$ at 3; Garry Toffoli \& Paul Benoit, "More Is Needed to Change the Rules of Succession for Canada," 36 Canadian Parliamentary Review 10 at 10, 11, 12.

5 Paul Lordon, Crown Law (Markham: Butterworths Canada, 1991) at 5 [Lordon]; Sir William Blackstone, Commentaries on the Laws of England in Four Books, vol 1 (Philadelphia: JB Lippincott, 1891) at 469 [Blackstone]; United Kingdom, Law Commission of the United Kingdom, The
Execution of Deeds and Documents by or on Behalf of Bodies Corporate (London: Ministry of Justice, 1998) at 26, online: The Law Commission <http://lawcommission.justice.gov.uk/docs/ cp143_Execution_of_Deeds_and_Documents_ Consultation.pdf $>$ [Law Commission].

6 Industry Canada, "Corporate and Insolvency Law Policy: Corporations Sole," online: Government of Canada <http://www.ic.gc.ca/eic/site/cilp-pdci. nsf/eng/cl00384.html $>$.

7 Law Commission, supra note 5.

8 Peter Hogg, "The Crown," Constitutional Law of Canada. 5th ed (Toronto: Thomson Reuters, 2012): 10-1 to 10-2 [Hogg Constitutional]; $R v$ Zornes, [1923] SCR 257(QL); Founders Square Ltd $v$ Nova Scotia (Attorney General), 175 NSR (2d) 391 at para 5 (QL), 33 CPC (4th) 202; Founders Square Ltd $v$ Nova Scotia (Attorney General), 2001 NSCA 49 at para 88, 192 NSR (2d) 127; $R v$ British Columbia, 1992 CanLII 164 (BC SC) at 5, ) 66 BCLR (2d) 84 (QL); Rochon (Litigation Guardian of) v British Columbia, 2007 BCSC 1060 at para 19, [2007] BCJ No 1634; Melnyk v Wiwchar, [2007] SKQB 118 para 9, 295 Sask R 125; The Queen $v$ The Canadian Broadcasting Corporation, 1958 CanLII 14 (ON CA) at paras 60-61, [1958] OR 55-85 (QL); Irving Shipyard Inc $v$ Canada (Attorney General), 2009 FCA 116 at para. 21, 314 DLR (4th) 340; Montana Band v Canada (TD), [1998] 2 FC 3, [1997] FCJ No 1486.

9 McAteer et al $v$ Attorney General of Canada, 2013 ONSC 5895 at paras 16-18, 20, 60, 62, 65, 290 CRR (2d) 332 [McAteer].

10 Canada, Law Reform Commission of Canada, Working Paper 40: The Legal Status of the Federal Administration (Ottawa: 1985) at 6.

11 Blackstone, supra note 5 at 475; Lordon, supra note 5 .

12 Hogg Constitutional, supra note 5.

13 Thomas Hobbes, Leviathan: Or The Matter, Forme and Power of a Commonwealth Ecclesiasticall and Civil, ed Edwin Curley (Cambridge, MA: Hackett Publishing Company, 1994) at 120, 124, 155-156.

14 Lordon, supra note 5.

15 As noted in Canadian Broadcasting Corporation v the Attorney General of Ontario (1958), ON CA 14, at paras 60-61: "It is important that at the outset we should understand the connotation of the words 'Her Majesty' in the Act. When Parliament names Her Majesty in a statute it means Her Majesty, not in her capacity as a natural person but in her capacity as a corporation sole, a persona ficta. [...] It is in that capacity that the Queen as sovereign, exercises her executive powers. The statute that 
regulates the conduct of persons within Canada,in the instant case, The Lord's Day Act,-could have no application to natural persons outside of Canada and therefore would not apply to Her Majesty in her capacity as a natural person because in that capacity she is outside of Canada. The legal fiction which recognizes this duality of persons in Her Majesty must also recognize that in her capacity as a corporation sole Her Majesty at all times is in every part of her realm. In those parts of her realm in which she is not physically present she is represented by her constitutional agents."

16 Blackstone, supra note 5 at 469.

17 The British Crown emerged as a corporation sole through common law rather than by act of parliament, and the Crown of Canada inherited this characteristic after it branched off from the Imperial Crown upon the passage of the Statute of Westminster, 1931 (UK), 22\& 23 Geo V, c 4. Lordon thus describes them as "non-statutory" corporations sole. See Lordon, supra note 5. In contrast, the Governor General of Canada is a statutory corporation sole by virtue of the Governor General's Act, RSC 1985, c G-9, and all the provincial legislatures have also all passed laws making their provincial Lieutenant Governors statutory corporations sole. The Governor General of Canada first became a corporation sole in 1868: "The Governor General of Canada [...] and his successors shall be a Corporation sole." An Act Respecting the Governor General, the Civil List, and the Salaries of certain Public Functionaries, 1868 (UK), 31 Vict, c 33, s 1.

18 Ernest H Kantorowicz, The King's Two Bodies: A Study in Mediaeval Political Theology (Princeton: Princeton University Press, 1957).

19 Ibid at 316.

20 Ibid.

21 Supra, note 9 at paras 60, 63, 65.

22 Crown Liability and Proceedings Act, RSC 1985, c C-50, s 2.

$23 R v$ Secretary of State for Foreign and Commonwealth AffairsEx $p$ Indian Association of Alberta, [1982] Q.B. 892 (C.A.) at 87 (WL), [1982] 2 WLR 641.

24 Hawkins, supra note 2.

25 Canada, Standing Senate Committee on Legal and Constitutional Affairs, Proceedings, 41st Parliament, 1st Sess, No 32 (20 March 2013) (Warren J Newman and Robert Nicholson); Hogg Succession, supra note 2.

26 Hawkins, supra note 2.

27 New Zealand, Bill 99-2, Royal Succession Bill, 2013, online: Parliamentary Council Office $<\mathrm{http} / / / \mathrm{www}$. legislation.govt.nz/bill/government/2013/0099/ latest/DLM5025805.html>.

28 Austl, Commonwealth, Council of Australian Governments, COAG Communique (Canberra: 19 April 2013) at 4, online: Council of Australian Governments $<$ http://www.coag.gov.au/node/498>.

29 Succession to the Crown 2013 (Qld), Schedule 1.

30 JR Mallory, The Structure of Canadian Government (Toronto: Macmillan, 1971) at 34-36.

31 House of Commons Debates (Hansard), 18th Parl, 2nd Sess, Vol 1 (19 January 1947) at 80 (Hon Ernest Lapointe).; House of Commons Debates (Hansard), 18th Parl, 2nd Sess, Vol 1 (19 January 1947) at 67 (Mr Mackenzie King).

32 House of Commons Debates (Hansard), 18th Parl, $2^{\text {nd }}$ Sess, Vol 1 (18 January 1937) at 43 (Mr Mackenzie King).

33 O'Donohue v Canada, [2003] CanLII 41404 (ONSC), [2003] OJ No 2764.

34 Interestingly, this logic would apply to the relationship between the Canadian Crown and the crowns of Canada's provinces. The Queen of Quebec, for instance, is and must be the same natural person as the Queen of Canada, because the province of Quebec is under the ultimate sovereign authority of the Crown of Canada. On the indivisibility of the Canadian Crown, see Henri Brun, Guy Tremblay \& Eugénie Brouillet, Droit Constitutionnel, 5e édition (Cowansville, QC: Éditions Yvon Blais, 2008) at 89.

35 Supra note 23.

36 Austl, Commonwealth, Australian Constitutional Commission, Final Report of the Constitutional Commission 1988 (Canberra: Australian Government Publishing Service, 1988) at 81, online: The University of Melbourne <http:// dtl.unimelb.edu.au/R/17XER682YI6X69EX VX4K17EI8EDEFML71GXNE8X7JFFPLQ H6HE-01014? func=dbin-jump-full\&object $\mathrm{id}=263980 \& 1$ ocal_base $=$ GEN $01 \& \mathrm{pds}$ handle=GUEST $>$; Sue $v$ Hill, (1999), 199 CLR 462 at para 93, [1999] HCA 30.

37 Memorandum from Robert Blackburn (November 2011) written evidence submitted to the Political and Constitutional Reform Committee on the Rules of Royal Succession, online: Parliament UK <http://www.publications.parliament.uk/pa/ cm201012/cmselect/cmpolcon/1615/1615we02. htm>.

38 Quentin Skinner, The Foundations of Modern Political Thought: Volume 1, The Renaissance (Cambridge: Cambridge University Press, 2007) at 9 . 
